\title{
Giving of Biochar and Biocompost to Growth, Results and N Uptake Soybean Plants (Glycyne Max (L) Merr.)
}

\author{
U’ul Efriyanti Prayoba, I Made Sudantha, Suwardji
}

\author{
Program Magister Pengelolaan Lahan Kering Universitas Mataram
}

\begin{abstract}
The use of biochar and biocompost can be one solution to the addition of organic matter in soybean cultivation. This study aims to obtain a good description of the role of biochar and biocompost on growth, yield, and $N$ uptake. The results of the study show that: (1) Application of biochar in soybean plants affects plant height, number of vacuous pods, number of pods containing, weight 100 seeds, and $N$ uptake compared with no biochar application. (2) Biocompost application has a significant effect on the height of soybean plants aged 2,3, 4 and 5 weeks after planting, dry weight, seed weight, number of vacuous pods and number of pods filled. (3) Biocompost with a liquid form dose of 2.5 grams/plant significantly affected the number of filled pods and the number of soybean pods. (4) Liquid biocompost dose of 5 grams/plant affects dry weight and plant height of $2 \mathrm{MST}$. While the $7.5 \mathrm{gram} / \mathrm{plant}$ liquid biocompost has an effect on the weight of soybean seed plants.
\end{abstract}

Keywords-Biochar, Biocompost, and Soybeans.

\section{INTRODUCTION}

Soybean (Glycine max L) is one of the food plants that plays an important role in Indonesia. Annual domestic soybean consumption is estimated at 2.6 million tons to 2.7 million tons. Soybean production in Indonesia alone has not been able to offset these needs (Reily, 2018).In NTB the harvest area and soybean production from 2015-2017 also decreased, which in 2015, soybean production reached 125,036 tons/ha with a planting area of 94,948 ha experiencing a drastic decrease in production to 56,097 tons/ha with an area of 43,149 ha in 2017. Soybean yield potential (tons/ha) in NTB also decreased from 1,316 tons/ha (2015) to 1.3 tons/ha (2017) (Kementerian Pertanian, 2017). This decrease in production is caused by various factors such as soil factors, climate, pests and diseases, and poor methods of land management. Therefore we need a variety of technological innovations that can increase soybean production, one of which is through land intensification. Efforts that can be made to increase the production output both the quality and quantity of soybean production are by adding organic matter in the soil.

Furthermore, the use of biochar and biocompost can be an alternative problem solver in soybean cultivation. Biochar is a material made from the pyrolysis process of organic matter and when deposited on the soil can function as a provider of soil carbon for a long time (Quiliam et al, 2013). From various research results, biochar combined with fertilizer can also increase soil nutrients in it which increases soil biota and nitrogen $(\mathrm{N})$ and phosphorus $(\mathrm{P})$ uptake (DeLuca et al, 2009).

Biocompost itself is compost made with the help of lignocellulolytic microbes that persist and act as controlling agents for plant diseases and decomposers of organic matter (Mastur, 2014). Sudantha (2007) reported that T.harzianum saprophytic fungi SAPRO-07 isolates and $\mathrm{T}$. koningii endophytic fungi ENDO-02 isolates were local superior microbial NTB as decomposers of organic matter.

The interaction of the influence of both is not well known. To obtain a good description of the role of biochar and biocompost on growth, yield and $\mathrm{N}$ uptake, this research needs to be carried out in depth. Therefore, the authors are interested in conducting a study of "Biochar and Biocompost Giving Responses to Growth, Yield and Absorption of Soybean Plants (Glycyne Max (L) Merr.)".This study aims to determine the effect of biochar and biocompost administration on growth, yield and $\mathrm{N}$ uptake of soybean crop production on dry land.

\section{METHOD}

The ingredients used include: Anjasmoro variety soybean seeds, biochar ingredients, biocomposite ingredients, and Trichoderma spp. The research was carried out in the village of Montong Are, Kediri District. 
RESULTS AND DISCUSSION

Biochar Fermentation Trichoderma Application TestPlant height

Table.1: Average soybean plant height due to biochar administration at 2,3,4 and weeks after planting (MST).

\begin{tabular}{|l|l|l|l|l|}
\hline \multirow{2}{*}{ Treatment } & \multicolumn{4}{|l|}{ Plant Height $(\mathrm{cm})$} \\
\cline { 2 - 5 } & 2 MST & 3 MST & 4 MST & MST \\
\hline With biochar & $\left.15,07 \mathrm{a}^{*}\right)$ & $\left.19,10 \mathrm{a}^{*}\right)$ & $\left.25,09 \mathrm{a}^{*}\right)$ & $\left.31,14 \mathrm{a}^{*}\right)$ \\
\hline Without biochar & $13,96 \mathrm{~b}$ & $17,74 \mathrm{~b}$ & $22,49 \mathrm{~b}$ & $28,60 \mathrm{~b}$ \\
\hline BNJ 5\% & 0,44 & 0,51 & 0,53 & 0,41 \\
\hline
\end{tabular}

Based on Table 1, the effect of biochar has a significant effect on the height of soybean plants. The average height of soybean plants with the application of biochar was $15.07 \mathrm{~cm}$, whereas without biochar it was 13.96 $\mathrm{cm}$ in the parameters of plant height at 2 MST.Plant height at the age of 3 MST showed the average height of soybean plants with the application of biochar was $19.10 \mathrm{~cm}$, whereas without the application of biochar it was $17.74 \mathrm{~cm}$.

The parameters of plant age 4 MST showed that the average height of soybean plants with the application of biochar was $25.09 \mathrm{~cm}$, whereas without the application of biochar it was $22.49 \mathrm{~cm}$. The parameters of plant height 5 MST showed the average height of soybean plants with the application of biochar was $31.14 \mathrm{~cm}$, while those without biochar were $28.60 \mathrm{~cm}$.

Biochar can act as a trigger for plant growth and retain nutrients in the soil so that nutrients in the soil are not easily lost in the washing process in the soil and will ultimately affect the increase in yields (Lehmann et al., 2003).In addition, this Trichoderma fermented biochar provides macro nutrient and micro nutrient requirements, containing humic acid (humus) increasing soil cation exchange capacity, increasing soil microorganism life and can help increase soil pH (Lelu et al., 2017). Especially in $\mathrm{N}$ nutrient uptake which is important in supporting the growth of soybean plant height. Where according to Lingga and Marsono (2006), that the role of $\mathrm{N}$ is to accelerate overall growth, especially stems and leaves.

Number of vacuous pods and contains

Table.2: Average number of soybean pods with application of biochar fermented Trichoderma spp.

\begin{tabular}{|l|l|l|}
\hline Treatment & $\begin{array}{l}\text { Amount of vacuous Pods } \\
\text { (fruit) }\end{array}$ & $\begin{array}{l}\text { Number of pods } \\
\text { containing (fruit) }\end{array}$ \\
\hline With biochar & $\left.6,58 \mathrm{a}^{*}\right)$ & $\left.32,82 \mathrm{a}^{*}\right)$ \\
\hline $\begin{array}{l}\text { Without } \\
\text { biochar }\end{array}$ & $5,37 \mathrm{~b}$ & $30,46 \mathrm{~b}$ \\
\hline BNJ 5\% & 51,13 & 1,912 \\
\hline
\end{tabular}

Based on Table 2, biochar has a significant effect on the number of soybean empty pods where without the biochar application the highest number of empty pods is
6.58 pods. Whereas soybean plants applied by Trichoderma spp mushroom fermentation biochar have a low number of empty pods which are only 5,37 pods .

Giving of biochar also has a significant effect on the number of pods containing soybeans. Soybean plants with biochar have the highest number of pods, 32.82 pods. While soybean plants without the application of Trichoderma spp biochar fungal fermentation have a number of pods containing low which is 30.46 pods.

The addition of biochar itself can significantly increase plant growth and important nutrient uptake during flowering (Steiner, et al, 2008). It can also accelerate the flowering time of soybean plants faster and increase the number of filled pods (Sudantha, 2011). Biochar can spur soil biological functions by providing a growing habitat for soil microorganisms that have an effect on nutrient availability and enzymes (Gomez, et al, 2014). Because the condition around the plant becomes more porous, it is very possible the absorption of available nutrients and inorganic nutrients that affect the process of forming soybean pods (Thies and Rillig, 2009).

Biochar can spur soil biological functions by providing a growing habitat for soil microorganisms that have an effect on nutrient availability and enzymes (Gomez, et al, 2014). Because the condition around the plant becomes more porous, it is very possible for absorption of available nutrients and inorganic nutrients to influence the process of forming soybean pods (Thies and Rillig, 2009).

\section{Weight of 100 seeds}

Table.3: The average weight of 100 seeds of soybean plants with the application offermented Trichoderma spp.

\begin{tabular}{|l|l|}
\hline Treatment & Weight of 100 seeds $(\mathrm{g})$ \\
\hline With biochar & $\left.17.98 \mathrm{a}^{*}\right)$ \\
\hline Without biochar & $17,04 \mathrm{~b}$ \\
\hline BNJ 5\% & 0,772 \\
\hline
\end{tabular}

Based on Table 3, shows that the treatment of Trichoderma spp biochar fermentation has a significant effect and can improve the quality of soybean seed plants. This can be seen from the weight of 100 seeds treated with 
biochar. The average weight of 100 seeds is highest in the treatment with biochar, which is 17.85 grams and the lowest is in the control treatment (without biochar), which is 16.71 grams.

Improving the quality of soybean seeds due to the addition of Trichoderma spp fermented biochar is due to the ability of biochar to help fulfill the nutrients needed by plants for the vegetative and generative phases. Lingga (2003) explains that the nutrients needed by plants are available in sufficient quantities, the metabolic results will increase. Of course cell division, elongation and maturation of tissue becomes more perfect and fast so that the increase in volume and weight is getting faster which in the end plant growth will be better.

\section{N Uptake}

Table.4: Average N uptake of soybean plants with the application offermented Trichoderma spp.

\begin{tabular}{|l|l|}
\hline Treatment & N uptake (\%) \\
\hline With biochar & $\left.1.242 \mathrm{a}^{*}\right)$ \\
\hline Without biochar & $0.472 \mathrm{~b}$ \\
\hline BNJ 5\% & 0,096 \\
\hline
\end{tabular}

In table 4, it can be seen that biochar has a significant effect on soybean $\mathrm{N}$ uptake in the amount of $1.242 \%$. Compared with without biochar application which only shows $\mathrm{N}$ uptake of $0.472 \% . \mathrm{N}$ uptake in soybean plants is also strongly influenced by the addition of fermented biochar. This is consistent with the statement of Zwieten et al (2010) that the addition of biochar significantly increases $\mathrm{N}$ uptake with fertilizers in ferrosol soil. This is because biochar has a high absorption area, high porosity and various content of organic material which has the potential to increase cation exchange capacity, and absorption capacity when added to the soil (Rajakumar and Sankar, 2016).

Biokompos Fermentation Trichoderma Plant High Application Test

Table.5: Average height of soybean plants as a result of the influence of biocompost at ages 2,3,4, and 5 MST

\begin{tabular}{|l|l|}
\hline Treatment & $\begin{array}{l}\text { Seed weight per plant } \\
(\mathrm{g})\end{array}$ \\
\hline $\begin{array}{l}\text { with biocompost 7,5 gram } \\
\text { liquid/plant }\end{array}$ & $\left.10,40 \mathrm{a}^{*}\right)$ \\
\hline $\begin{array}{l}\text { with biocompost 2,5 gram } \\
\text { liquid/plant }\end{array}$ & $10,00 \mathrm{a}$ \\
\hline $\begin{array}{l}\text { with biocompost 5,0 gram } \\
\text { liquid/plant }\end{array}$ & $9,81 \mathrm{a}$ \\
\hline
\end{tabular}

www.ijeab.com

-

\begin{tabular}{|l|l|}
\hline $\begin{array}{l}\text { with biocompost 7,5 gram } \\
\text { liquid/plant }\end{array}$ & $9,78 \mathrm{~b}$ \\
\hline $\begin{array}{l}\text { with biocompost 2,5 gram } \\
\text { liquid/plant }\end{array}$ & $9,02 \mathrm{~b}$ \\
\hline $\begin{array}{l}\text { with biocompost 5,0 gram } \\
\text { liquid/plant }\end{array}$ & $8,96 \mathrm{~b}$ \\
\hline Without biocompost & $7,23 \mathrm{c}$ \\
\hline
\end{tabular}

Based on table 7, soybean plants without biocompost application have a significant effect on the weight of soybean seeds, which is weighing 7.23 grams. The application of biocompost in the form of a liquid that is a dose of 7.5 grams / plant has the largest seed weight of 10.40 grams and the lowest weight of soybean seeds obtained in biocompost treatment in granular form with a dose of 5 grams / plant weighing 8.96 grams.

Of course the administration of biocompost is very appropriate because it can increase nutrient availability, increase nutrient efficiency and take nutrients during fertilizer application (Agegnehu et al, 2015; Jeffery, et.al, 2011).

Rizqiani et al (2007) stated that absorbed elements can be used to encourage cell division and the formation of new cells to form better organ organs such as leaves, stems and roots so as to facilitate photosynthesis.

\section{Dry Sturdy Weight}

Table.8: Average dry weight of soybean plants by application of biocompost fermented Trichoderma spp

\begin{tabular}{|l|l|}
\hline Treatment & Dry weight (gr) \\
\hline $\begin{array}{l}\text { with biocompost 5,0 gram } \\
\text { granules/plants }\end{array}$ & $\left.11,55 \mathrm{a}^{*}\right)$ \\
\hline $\begin{array}{l}\text { with biocompost 7,5 gram } \\
\text { granules/plants }\end{array}$ & $10,54 \mathrm{a}$ \\
\hline $\begin{array}{l}\text { with biocompost 7,5 gram } \\
\text { granules/plants }\end{array}$ & $10,48 \mathrm{a}$ \\
\hline $\begin{array}{l}\text { with biocompost 2,5 gram } \\
\text { granules/plants }\end{array}$ & $10,43 \mathrm{a}$ \\
\hline $\begin{array}{l}\text { with biocompost 2,5 gram } \\
\text { granules/plants }\end{array}$ & $10,43 \mathrm{a}$ \\
\hline $\begin{array}{l}\text { with biocompost 5,0 gram } \\
\text { granules/plants }\end{array}$ & $9,8 \mathrm{~b}$ \\
\hline Without biocompost & $7,23 \mathrm{c}$ \\
\hline
\end{tabular}

Based on table 8, soybean plants without the application of biocompost to soybean plants have no significant effect on the dry weight of soybean plants which is 7.23 grams. The application of biocompost in the form of liquid with a dose of 5 grams / plant has the highest dry weight, which is weighing 11.55 grams and the lowest

Page | 252 
weight weight is obtained in biocompost treatment in granular form with a dose of 5 grams / plant weighing 9.8 grams.

The difference in dry weight between treatments without biocompost and given biocompost application shows that biocompost is able to provide sufficient amounts of nutrients needed. Lingga (2003) explains that if nutrients are sufficient for plants, metabolic synthesis will increase.

Addition of soil organic matter such as biocompost from Trichoderma spp. this is very influential on the absorption of nutrients in soybean plants. This Trichoderma spp mushroom serves as a source of nutrients for plants and energy sources for soil organisms and helps plants to grow and develop better (Sudantha, 2010a).

\section{CONCLUTION}

1. The application of biochar on soybean plants affects plant height, number of empty pods, number of pods containing, weight of 100 seeds, and $\mathrm{N}$ uptake compared with without biochar application.

2. The biocompos application has a significant effect on the height of soybean plants aged 2.3, 4 and 5 weeks after planting, dry weight, seed weight, number of empty pods and number of pods filled.

3. Biocompost with a liquid form of 2.5 grams/plant has a significant effect on the number of filled pods and the number of soybean pods. Liquid biocompost dose of 5 grams / plant has an effect on dry weight and plant height at 2 MST. While the 7.5 gram/plant liquid biocompost has an effect on the weight of soybean seed plants.

4. Biocompost granules of 7.5 gram dosage / plant plants have an effect on plant height aged 3 and 5 MST. While the dose of 2.5 grams of granules / plants affects the height of soybean plants aged 4 MST.

\section{REFERENCES}

[1] Agegnehu,G.,Bass,S.A.,Neloson P.N, Muirhead B, Wright G, Bird M.I. 2015. Bichar and biocharcompost as soil amandement effects on peanut yield soil properties and greenhouse gas emission in tropical North Queensland Australia. Agric Ecosyst. Environ 213,p 72-85.

[2] Novizan.2004. Petunjuk Pemupukan yang Efektif.Agro Media Utama. Jakarta.

[3] Rajamakumar, R and Jayasree Sankar. 2016. Biochar For Sustainable Agriculture-A Review. International Journal of Applied and Pure Science and Agriculture.

[4] Reily, Michael. 2018. Konsumsi Tempe Tunun, Impor Kedelai Menyusut. https://katadata.co.id/berita/2018/09/20/konsumsitempe-turun-impor-kedelai-menyusut._Diakses tanggal 8 Januari 2018.

[5] Quiliam, Richard S, Thomas H De Luca, Davey L Jones. 2013. Biochar Aplication Reduces Nodulation But Increase Nitrogenase Activity In Clover. Plant Soil (2013) 366: 83-92.

[6] Steiner C 2007. Soil Charcoal Amendments Maintain Soil Fertility and Establish Carbon Sink-Research and Prospects. Soil Ecology Res Dev. 1 - 6.

[7] Sudantha, 2010. Pengujian beberapa jenis jamur endofit dan saprofit Trichoderma spp. Terhadap penyakit layu fusarium pada tanaman kedelai. http://fp.unram.ac.id/data/2012/04/20-2-2 02sudantha_rev-wangiyanap.pdf. Diunduh pada tanggal 17 juni 2016.

[8] Sudantha, 2011. Buku Teknologi Tepat Guna : Penerapan Biofungisida dan Biokompos Pada pertanian Organik. Fakultas Pertanian Universitas Mataram, Mataram.

[9] Sudantha, I Made dan Suwardji. 2016. Pemanfaatan Bioaktivator dan Biokompos (Mengandung Jamur Trichoderma Spp dan Mikoriza) Untuk Meningkatkan Kesehatan, Pertumbuhan, dan Hasil Tanaman Kedelai di Lahan Kering. Universitas Mataram. Mataram.

[10] Thies, Janice E. and Matthias C.Rillig. 2009. Characteristics of Biochar: Biological Properties. Biochar for Environmental Management.Eartscan. London.p 85 - 105

[11] Zwieten, L. Van, S. Kimber \& S. Morris, K. Y. Chan \& A. Downie, J. Rust, S. Joseph \& A. Cowie. 2009. Effects Of Biochar From Slow Pyrolysis Of Papermill Waste On Agronomic Performance And Soil Fertility. Springer Science + Business Media B.V. 2009.

[12] Lingga, P. 2003. Petunjuk Penggunaan Pupuk. Penebar Swadaya. Jakarta

[13] Lingga dan Marsono. 2006. Petunjuk Penggunaan Pupuk. Penebar Swadaya. Jakarta.

[14] Mastur. 2014. Uji Dosis Dan Cara Aplikasi Biokompos Hasil Fermentasi Jamur Endofit Dan Saprofit Trichoderma sp. Dalam Meingkatkan Pertumbuhan Dan Hasil Tanaman Jagung Hibrida Di Lahan Kering. Tesis. 